\title{
The prevalence of African animal trypanosomoses AND TSETSE PRESENCE IN WeSTERN SENEGAL
}

\author{
SECK M.T.*, BOUYER J.****, SALL B.***, BENGALY Z.***** \& VREYSEN M.J.B.*****
}

\section{Summary:}

In 2005, the Government of Senegal initiated a tsetse eradication campaign in the Niayes and La Petite Côte aiming at the removal of African Animal Trypanosomosis (AAT), which is one of the main constraints to the development of more effective cattle production systems. The target area has particular meteorological and ecological characteristics that provide great potential for animal production, but it is unfortunately still infested by the riverine tsetse species Glossina palpalis gambiensis Vanderplank (Diptera: Glossinidae). The tsetse project in Senegal has adopted an areawide integrated pest management (AW-IPM) approach that targets the entire tsetse population within a delimited area. During the first phase of the programme, a feasibility study was conducted that included the collection of entomological, veterinary, population genetics, environmental and socio-economic baseline data. This paper presents the parasitological and serological prevalence data of AAT in cattle residing inside and outside the tsetse-infested areas of the target zone prior to the control effort. At the herd level, a mean parasitological prevalence of $2.4 \%$ was observed, whereas a serological prevalence of $28.7 \%, 4.4 \%$, and $0.3 \%$ was obtained for Trypanosoma vivax, T. congolense and T. brucei brucei, respectively. The observed infection risk was 3 times higher for $T$. congolense and $T$. vivax in the tsetse-infested than in the assumed tsetse-free areas. Moreover, AAT prevalence decreased significantly with distance from the nearest tsetse captured which indicated that cyclical transmission of the parasites by tsetse was predominant over mechanical transmission by numerous other biting flies present. The importance of these results for the development of a control strategy for the planned AW-IPM campaign is discussed.

KEY WORDS: African animal trypanosomosis, tsetse, cyclical transmission, mechanical transmission, area-wide integrated pest management, feasibility study, Senegal.
Résumé : PRÉVAlENCE deS tRYPANOSOMOSES ANIMALES AFRICAINES ET PRÉSENCE DES GLOSSINES DANS L'OUEST DU SÉNÉGAL

En 2005, le Gouvernement du Sénégal a initié une campagne d'élimination des glossines dans la zone des Niayes et La Petite Côte dans le but de supprimer les Trypanosomoses Animales Africaines (TAA), qui font partie des contraintes principales au développement des systèmes de production intensifs. La zone cible présente des conditions climatiques et écologiques particulières avec un potentiel de production animale important, mais elle est malheureusement toujours infestée par l'espèce de glossine riveraine Glossina palpalis gambiensis Vanderplank (Diptera: Glossinidae). Le projet d'élimination des glossines a adopté une stratégie de gestion intégrée des ravageurs à l'échelle d'une population totale dans une zone donnée. La première phase du programme correspond à une étude de faisabilité qui inclut la collecte de données de base entomologiques, vétérinaires, génétiques, environnementales et socio-économiques. Cet article présente les données de prévalence parasitologique et sérologique dans et hors de la zone infestée par les glossines avant le début de la lutte. La prévalence parasitologique moyenne intra-troupeav était de 2,4\%, alors que la prévalence sérologique était de 28,7\%, 4,4\% et 0,3\% pour Trypanosoma vivax, T. congolense et T. brucei brucei respectivement. Le risque d'infection observé était troi3 fois plus élevé dans la zone infestée par les glossines que dans la zone considérée comme non-infestée. De plus, la prévalence diminuait significativement avec la distance à la glossine capturée la plus proche, ce qui indique que la transmission cyclique des parasites domine, par rapport à la transmission mécanique par de nombreux autres insectes piqueurs présents. L'importance de ces résultats pour le développement de la stratégie de lutte intégrée est discutée.

MOTS CLÉS : trypanosomose animale africaine, tsé-tsé, transmission cyclique, transmission mécanique, gestion intégrée des ravageurs, etude de faisabilité, Sénégal.

\footnotetext{
* Institut Sénégalais de Recherches Agricoles, Laboratoire National d'Élevage et de Recherches Vétérinaires, Service de Parasitologie, BP 2057, Dakar - Hann, Sénégal.

** Cirad, UMR Contrôle des maladies animales exotiques et émergentes, Campus International de Baillarguet, F-34398, Montpellier, France.

**** Direction des Services Vétérinaires, 37, avenue Pasteur, BP 67 Dakar, Sénégal.

***** Centre International de Recherche-développement sur l'Élevage en Zone Subhumide, BP 454, Bobo-Dioulasso, Burkina Faso.

****** Insect Pest Control Laboratory, Joint FAO/IAEA Programme of Nuclear Techniques in Food and Agriculture, PO Box 100, Wagramerstrasse 5, A-1400 Vienna, Austria.

Correspondence: Momar Talla Seck

Tel.: 00221338323678 - Fax: 00221338323679

E-mail : mtseck@hotmail.fr
}

\section{INTODUCTION}

1 The Niayes area and La Petite Côte are located along the Atlantic coast of Senegal and include four administrative districts: Dakar, Thies, Louga and Saint-Louis. Particular meteorological and ecological characteristics of this area provide great potential for agricultural development in general and animal production (cattle, donkeys, horses, small ruminants, pigs and poultry) in particular. Most of these animals are however susceptible to the debilitating disease African Animal Trypanosomosis (AAT) (Mulligan, 1970) which is widespread in sub-Saharan Africa (Itard et al., 2003). AAT is 
indeed the main constraint to the development of more effective cattle production systems in African countries infested with tsetse (Itard et al., 2003), their cyclical vectors. Details of the infestation of the Niayes area and Petite Côte with Glossina palpalis gambiensis Vanderplank (Diptera: Glossinidae) were already collected in the 1960s (Morel \& Touré, 1967; Touré, 1971, 1974), which was followed by eradication attempts in the $1970 \mathrm{~s}$ and 1980s using mainly ground spraying of residual insecticides (Touré, 1973). Thereafter, the tsetse and trypanosomosis problem seemed to have disappeared, which allowed the introduction of exotic cattle breeds in the area (Ba Diao, 2005) but flies were detected again in 1998 (unpublished report of the Direction des Services Vétérinaires Services (DSV)). The maintenance of these exotic cattle (Holstein, Jersey, Montbeliard, etc) in zero ground-grazing units has only been possible by keeping these trypano-susceptible animals under constant prophylactic treatment with trypanocidal drugs, which is not only cost ineffective but not sustainable in the long term. AAT remains a major pathological problem in the area, where the mean daily milk production is still limited to $6.9 \mathrm{~kg}$ (s.d. 3) despite much higher genetic potential of these exotic breeds (Ba Diao, 2005).

In 2005, the DSV initiated a campaign called "Projet de lutte contre les glossines dans les Niayes" with the goal to develop a sustainable solution to the tsetse and trypanosomosis problem in the Niayes. The programme is funded by the Government of Senegal and technically and financially supported by the International Atomic Energy Agency (IAEA), the Food and Agriculture Organization of the United Nations (FAO) and the Centre de Coopération Internationale en Recherche Agronomique pour le Développement (CIRAD). The project is being implemented in the context of the Pan African Tsetse and Trypanosomiasis Eradication Campaign (PATTEC), a political initiative of the African heads of state that calls for increased efforts to manage the tsetse and trypanosomosis problem in sub-Saharan Africa (http:// www.africa-union.org/ Structure of the Commission/ depPattec.htm). The tsetse project in Senegal has adopted an area-wide integrated pest management (AWIPM) approach that aims at integrating various control tactics (e.g. traps and insecticide-impregnated targets (Bauer et al., 2005; Green, 1994), live baits (Bauer et al., 1995; Bouyer et al., 2009; Bouyer et al., 2007), and the sterile insect technique (SIT) (Dyck et al., 2005)) to target an entire tsetse population within a circumscribed area (Klassen, 2005).

As a first phase of this project, entomological, veterinary, and population genetics baseline data have been collected as part of a feasibility study (Bouyer et al., 2010; Solano et al., 2010). The collection of socio-economic and environmental data will complete the feasibility study effort. The DSV, the Institut Sénégalais de
Recherches Agricoles (ISRA), and the Centre de Suivi Ecologique (CSE) implemented this feasibility study to assess whether a sustainable zone free of G. p. gambiensis can be created in the Niayes and La Petite Côte. In addition, the data collected would constitute a base of reference data that would allow the evaluation of the progress and cost-effectiveness of a future control campaign. For the entomological baseline data study, a stratified sampling procedure was developed using geographical information systems (GIS), remote sensing data and probability models to ascertain the current distribution of tsetse in the target area (Bouyer et al., 2010). Trapping data from 683 unbaited Vavoua traps deployed between January 2008 and February 2009 showed that G.p.gambiensis was the only species present in the area and was distributed in an area of $525 \mathrm{~km}^{2}$ of the Niayes and La Petite Côte (Fig. 1). No tsetse flies were sampled between the Niayes and the Sine Saloum (Missira), which is situated more than $100 \mathrm{~km}$ to the south-east of the Niayes. The zero catches in this area provided the first indications that the G. $p$. gambiensis populations of the Niayes were isolated from the remainder of the tsetse belt in south-eastern Senegal (Bouyer et al., 2010). Using three markers (microsatellite DNA, mitochondrial COI DNA, and geometric morphometrics) a population genetic study revealed the absence of gene exchange between the G. p. gambiensis populations in the Niayes and those of the Sine Saloum (Missira), confirming the results of the entomological surveys that the populations of the Niayes can be considered isolated (Solano et al., 2010). This paper presents the results of the veterinary survey, i.e. the parasitological and serological prevalence data of AAT in cattle in the target zone prior to the control effort, both inside and outside the tsetse-infested areas.

\section{MATERIELS AND METHODS}

\section{STUDY AREA AND PERIOD}

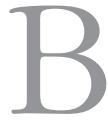
etween 30 August and 26 October 2007, the veterinary survey was conducted in 38 sites, which were geo-referenced using global positioning system (GPS) units (Fig. 1). These sites were randomly selected, since the tsetse distribution was not known at that time. In each of the sampling sites, blood was taken from the jugular vein of cattle that were declared sedentary to the Niayes and La Petite Côte by their owners. In herds that contained more than 50 animals, sampling was limited to 50 animals, whereas in smaller herds, all animals were sampled. From each animal, one blood sample was taken in a dry vacutainer tube and another in a vacutainer tube containing the anticoagulant ethylene diamine tetra acetic acid (EDTA). Blood samples were collected from in total 1,332 cattle belonging to 74 herds. 


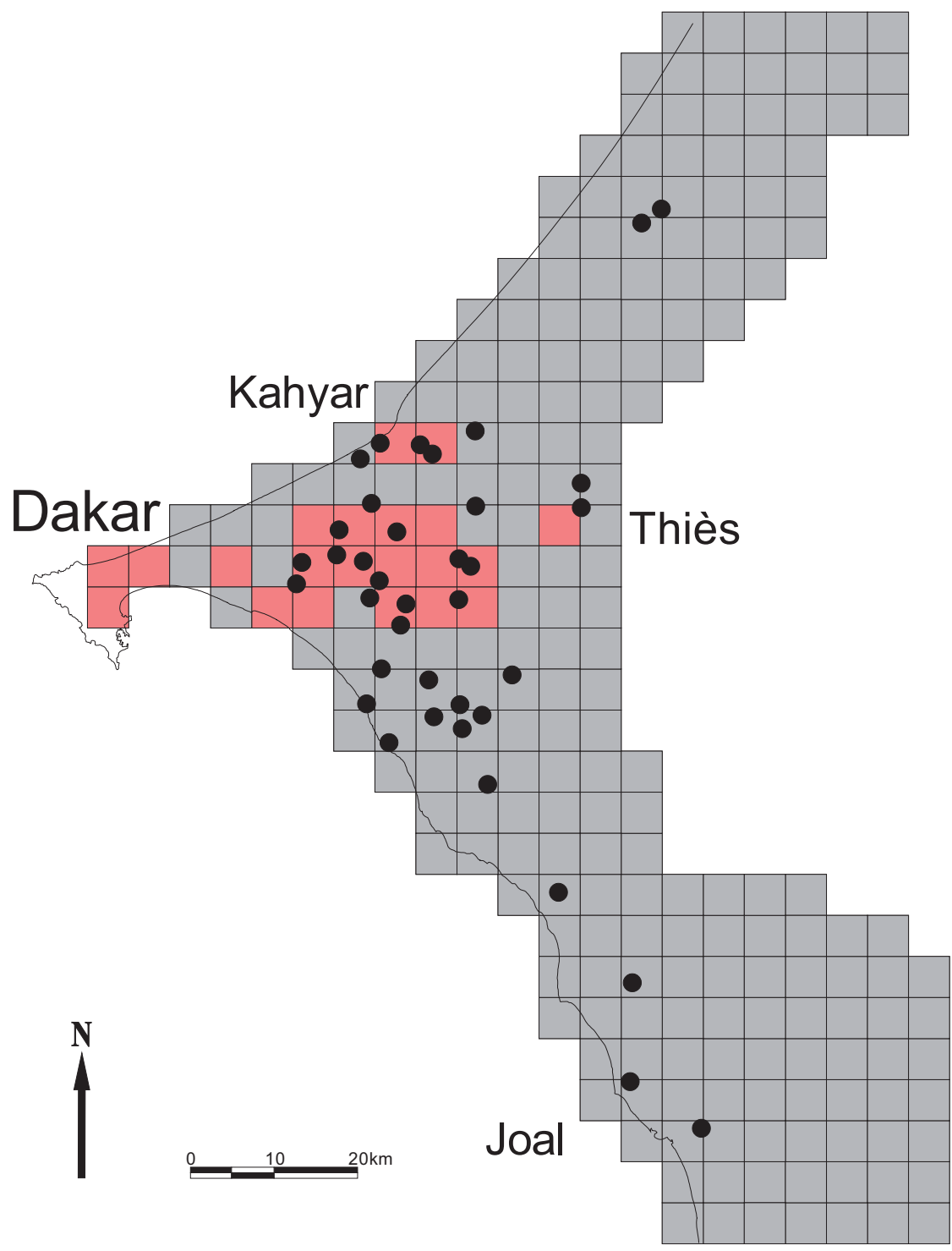

Fig. 1. - Location of the sampled herds and distribution of Glossina palpalis gambiensis in the Niayes area and La Petite Côte (presence $=$ red, absence of record $=$ grey $)$.

\section{LABORATORY ANALYSES}

Three diagnostic techniques were used to assess AAT prevalence: direct examination of the Buffy coat using the dark ground hematocrite centrigufe technique (DGHCT) for morphological identification $\left(G^{*} 20\right)$, a serological analysis using the Ab-enzyme-linked immunosorbent assay (ELISA) (Desquesnes et al., 2001) and Polymerase Chain Reaction (PCR) (Desquesnes \& Davila, 2002; Lefrançois et al., 1998) on the positive samples to confirm the species of trypanosome involved. For the DG-HCT, blood subsamples were centrifuged in hematocrite tubes at 15,000 rounds/min during 5 minutes. The interphase of 1,141 samples was examined between slide and thin strip using a phase contrast microscope. All the 1,332 serum samples were tested for Trypanosoma brucei brucei, T. congolense and T. vivax using the Ab-ELISA technique. Monospecific primers of T. vivax, T. brucei sensu lato and T. congolense savannah type (Desquesnes \& Davila, 2002; Lefrançois et al., 1998) were used for a PCR analysis which was carried out at the Centre International de Recherche-Développement sur l'Elevage en zone Sub-humide (CIRDES) in Burkina Faso.

\section{STATISTICAL ANALYSES}

The relationship between AAT prevalence and (1) tsetse presence, (2) tsetse apparent density, and (3) distance to the nearest trapped tsetse fly was assessed. For the first analysis, the AAT prevalence of herds located inside and in a buffer of $5 \mathrm{~km}$ around the known tsetseinfested area (to account for herd grazing distance), henceforth denoted 'tsetse-infested area', was compared to that of the area were the probability of presence of tsetse was below 0.05 , henceforth denoted 'assumed tsetse-free area' (Bouyer et al., 2010). The normality of the distribution in each area was tested 


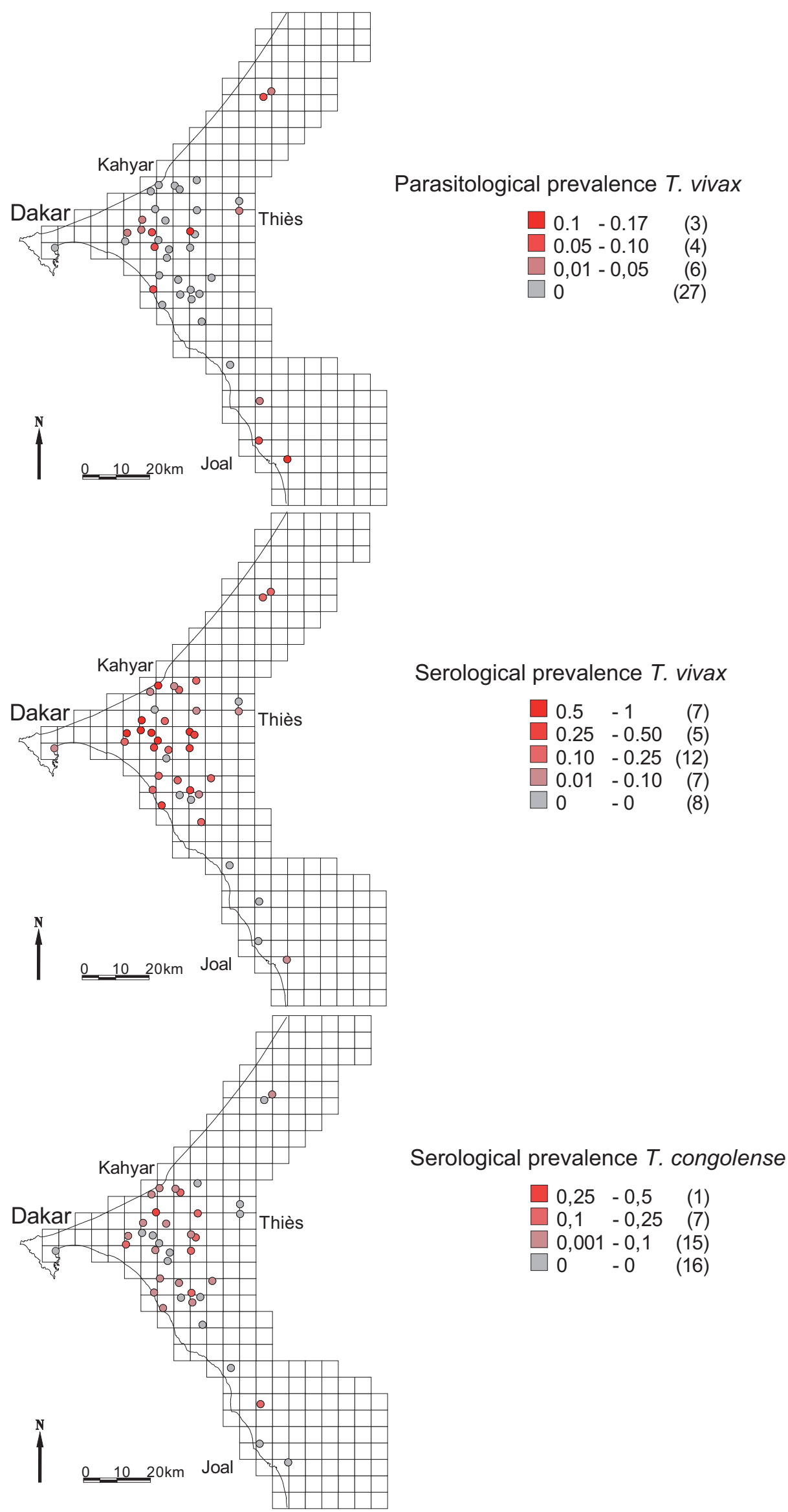

Fig. 2. - From top to bottom: herd parasitological prevalence of $T$. vivax, herd serological prevalence of T. vivax and T. congolense in the Niayes and La Petite Côte.

Parasitological prevalence $T$. vivax

(6)

(27)

\begin{tabular}{|c|c|c|}
\hline 05 & -1 & (7) \\
\hline U. & -0.50 & (5 \\
\hline & -0.25 & (12 \\
\hline & -0.10 & (7 \\
\hline & -0 & \\
\hline
\end{tabular}

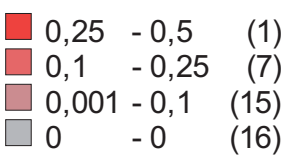


using the Kolmogorov-Smirnov test (Conover, 1971). Theirs variances were then compared using a $\mathrm{F}$ test and their means using a Student $t$ test. To reduce the effects of animal mobility, the same analyses were repeated using only young cattle ( $<3$ years old) corresponding to 304 animals. Even if the herds are currently sedentary, old animals may still contain antibodies resulting from immune responses of past contacts with trypanosomes in tsetse-infested areas.

The correlation between the apparent density of tsetse and the AAT prevalence within the tsetse-infested area was assessed at the grid cell level [the area was subdivided in grid cells of $5 \times 5 \mathrm{~km}$ to facilitate sampling procedures (Bouyer et al., 2010)] using the Kendall's correlation test (Fig. 1).

Finally, the correlation between herd prevalence in young cattle and the distance to the nearest tsetse captured was investigated using Pearson's correlation test, after logarithmic transformation $(\ln (\mathrm{x}+1))$ of the herd prevalence rates.

\section{RESULTS}

\section{PARASITOLOGICAL PREVALENCE}

Animals positive for AAT were detected in 13 out of the 38 sites sampled. Among the 1,141 cattle analysed using the DG-HCT, 23 were positive, corresponding to a mean herd prevalence of $2.4 \%$ (s.d. $4.3 \%$ ). Among the herds found positive with the DG-HCT, the prevalence varied between $2.6 \%$ in Séguile Coopé (Mboro) and 13.3\% in Fadial (Joal) and Ndiakhaté (Pout) (Fig. 2). The parasitological analysis did not reveal the presence of $T$. congolense and all infections were attributed to $T$. vivax. No significant difference was observed between the parasitological prevalence of $T$. vivax in tsetseinfested and in the assumed tsetse-free areas $(\mathrm{p}=0.88)$. However, the parasitological prevalence of T. vivax in young animals was negatively correlated with distance to the nearest tsetse captured (Fig. 3, $\mathrm{r}=-0.41$, $p=0.016)$. Inside the tsetse-infested area, the apparent density of tsetse was not correlated with the parasitological prevalence of T. vivax $(\mathrm{p}=0.49)$.

Among the 23 samples positive using the DG-HCT, a PCR analysis identified eight samples as T. vivax, whereas the others were negative for all trypanosome species. This might be due to a bad conservation of the samples during their transport from Senegal to Burkina Faso or to different T. vivax like trypanosomes.

\section{SEROLOGICAL ANALYSES}

The overall mean serological prevalence for all samples was $28.7 \%$ (s.d. $45.1 \%$ ), $4.4 \%$ (s.d. $20.2 \%$ ), and $0.3 \%$ (s.d. $4.7 \%$ ) for T. vivax, T. congolense and T. brucei brucei, respectively. Fig. 2 shows the serological prevalence per herd for T. vivax and T. congolense. The serological prevalence of T. vivax was significantly higher in the tsetse-infested (35.3\%, s.d. $33.5 \%)$ than in the assumed tsetse-free area (13.9\%, s.d. $11.7 \%)$ $(\mathrm{p}=0.011)$, with a difference of $21.5 \%$ [95 \% CI: 5.4$37.5 \%$ ]. The serological prevalence of $T$. congolense was not significantly different between the two areas $(\mathrm{p}=0.09)$.

This difference however became significant for both Trypanosoma species when only animals younger than three years were taken into consideration. In this age group the serological prevalence of T. vivax was $30.0 \%$ (s.d. $33.6 \%$ ) in the tsetse-infested area and $8.3 \%$ (s.d. $13.2 \%)$ in the assumed tsetse-free area, corresponding to a difference of $21.7 \%$ [95 \% CI: 4.5-38.9\%] ( $\mathrm{p}=0.013$ ). For T. congolense a serological prevalence of $6.0 \%$ (s.d. $9.7 \%$ ) was obtained for the tsetse-infested areas versus $1.2 \%$ (s.d. $2.4 \%$ ) for the assumed tsetse-free areas $(\mathrm{p}=0.05)$, corresponding to a difference of $4.9 \%$ [95\% CI: $0.3-9.4 \%]$. For this age group, the serological prevalence of T. vivax was also negatively correlated with distance to the nearest tsetse captured $(r=-0.41$, $\mathrm{p}=0.015)$. This was not the case for $T$. congolense $(\mathrm{p}=0.34)$.

In the tsetse-infested area, the serological prevalence of $T$. vivax was highly correlated with the apparent density of tsetse (tau $=0.423, \mathrm{p}=0.008)$. This correlation was not significant for $T$. congolense $(\mathrm{p}=0.36)$. The highest serological prevalence of T. vivax (96\%) and T. congolense $(30 \%)$ was observed in Diacksao Peuhl and Bahyakh, respectively, which are situated in the middle of the known tsetse-infested area.

\section{DISCUSSION}

The Government of Senegal has recently embarked on a national program to intensify dairy production in the Niayes through the improvement of local cattle breeds through artificial inseminations with sperm from exotic, more productive breeds. Despite two tsetse control campaigns in the Niayes in the 1970s and 1980s (Touré, 1973), the tsetse fly G.p.gambiensis and the disease AAT persisted and remain a serious impediment to the development of the livestock sector. The Ministry of Livestock and its partners (ISRA-LNERV, CSE, CIRAD, FAO/IAEA) have therefore initiated a study to assess whether the removal of the G.p.gambiensis population from the Niayes using an area-wide integrated pest management approach (Vreysen et al., 2007) will be feasible. Such a study would provide comprehensive data sets to serve as the underlying basis for the development of a scientifically sound intervention strategy and the necessary baseline data to monitor programme progress. 
The results of the parasitological and serological survey reported in this paper indicated that T. vivax was the predominant trypanosome species in the Niayes with zero parasitological prevalence rates for $T$. congolense. These results are in accordance with observations in other sites of the northern tsetse belt in West Africa (Bouyer et al., 2006; Guerrini \& Bouyer, 2007) and might be due to a lower intrinsic vectorial capacity of G.palpalis gambiensis for T. congolense in comparison with e.g. Glossina morsitans submorsitans Newstead or Glossina tachinoïdes Westwood (Reifenberg et al., 2008), two species common in West Africa but absent in the study area. Another hypothesis is a possible shorter lifespan of the G. p. gambiensis populations inhabiting the ecological marginal areas at the northern limit of their distribution, favouring trypanosome species with short extrinsic cycles (duration of the development of the parasite in the vector) (Bouyer et al., 2006; Van den Bossche et al., 2010).

The parasitological prevalence of T. vivax was low (2 \%) but was probably under-estimated, since recent results obtained in The Gambia suggest that the sensitivity of the buffy coat technique is only $50 \%$ (Faye et al., 2001). Another factor that might have reduced the apparent parasitological prevalence is the constant prophylactic treatment of the animals with trypanocidal drugs. In addition, in many parts of the study area, G. p. gambiensis was mainly encountered in mango and other fruit orchards where cattle is prohibited and the flies mostly feed on humans and dogs. This likewise reduces the transmission risk to cattle, lowers the prevalence rate and could also explain the high variability of the prevalence in herds located close to tsetse i.e. less than 5 km (Fig. 3).

The serological prevalence of T. congolense and T. vivax in young cattle was three times higher in the tsetseinfested than in the assumed tsetse-free areas. The presence of $T$. congolense in the Niayes is reported here for the first time and its wide distribution is worrying (Fig. 2) as the parasite is in general more pathogenic for cattle than T. vivax (Itard \& Frézil, 2003).

The serological prevalence of $T$. bruce $i$ was too low to confirm its presence in the study area, given the negative parasitological results and the low specificity of ELISA test at the individual level (Desquesnes et al., 2001). However, in December 2009, the presence of T. brucei s.l. was proven by a parasitological isolation from a wild G. p. gambiensis fly captured in Pout and fed on a goat.

The serological prevalence of T. vivax was positively correlated with tsetse density and negatively correlated with the distance to the nearest tsetse captured. The absence of a correlation between tsetse presence and density, the parasitological prevalence of both parasites and the serological prevalence of $T$. congolense is probably related to the very low values of the latter three parameters. Moreover, apparent fly density is not a good risk indicator and should be multiplied by tsetse infectious rate to better represent cyclical transmission (Bouyer et al., 2006; Guerrini \& Bouyer, 2007). However,
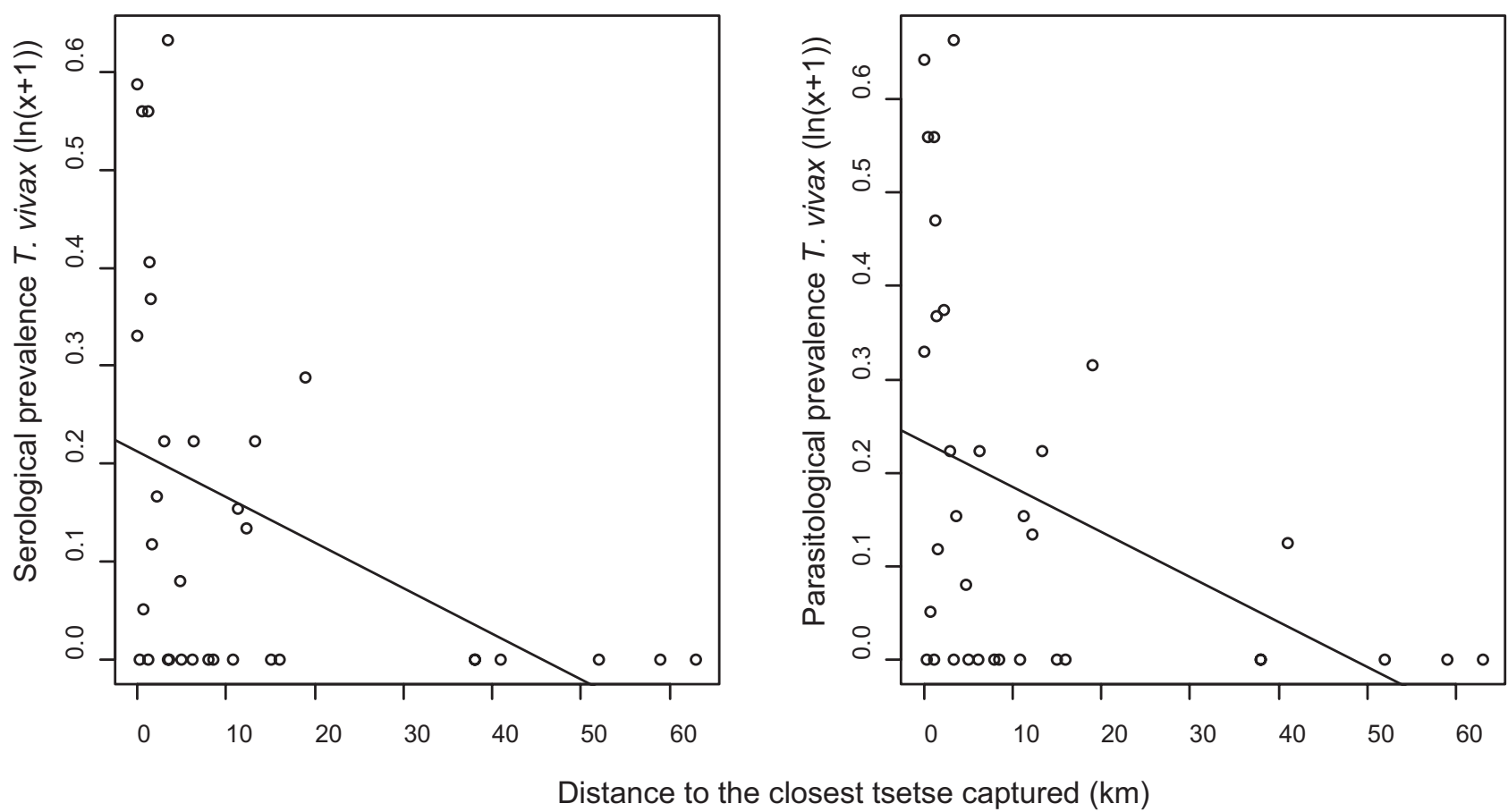

Fig. 3. - Correlation between serological (left) and parasitological (right) prevalence of T. vivax $(\ln (\mathrm{x}+1))$ and the distance to the nearest tsetse (G.p. gambiensis) captured. 
the importance of cyclical transmission of AAT in the study area is obvious from the presented results, even if evidence exists that $T$. congolense and $T$. vivax can also be transmitted mechanically by biting flies (Desquesnes et al., 2009; Desquesnes \& Dia, 2003a, b, 2004). It is therefore likely that the sustainable removal of the G.p.gambiensis population from the Niayes and La Petite Côte will greatly reduce the prevalence of AAT, possibly followed by its disappearance as was demonstrated on Unguja Island. Both T. congolense (which was the dominant species before the start of the eradication campaign) and T. vivax disappeared from the island following the eradication of Glossina austeni Newstead (Vreysen et al., 2000) despite very high densities of biting flies such as Stomoxyinae (Saleh et al., 1999). These biting flies were therefore not capable to maintain the transmission cycle of the trypanosomes after the removal of the cyclical vector, raising questions on the epidemiological importance of biting flies. Similar observations were made in Sidéradougou, Burkina Faso after the removal of G.p. gambiensis, G. tachinoides and G. morsitans submorsitans from $3,500 \mathrm{~km}^{2}$ of agropastoral land (Cuisance et al., 1984; Delafosse et al., 1996; Politzar \& Cuisance, 1984). It would therefore be very useful to assess the epidemiological dynamics and the potential role of these biting flies after the completion of the tsetse eradication campaign in the Niayes and La Petite Côte.

During the entomological surveys, many species of Tabanidae and Stomoxyinae were captured throughout the target area, but at low mean apparent densities of 0.2 flies/trap/day (s.d. 0.6) and 1.9 flies/trap/day (s.d. 12.4) respectively. In certain areas, apparent densities were as high as 5.7 flies/trap/day for Tabanidae and 286 flies/trap/day for Stomoxyinae. The serological prevalence of both parasite species was not zero in the assumed tsetse-free areas, indicating a possible role of these biting flies outside the tsetse area. However, the mobility of cattle and their dispersal in and out of the tsetse-infested area should not be neglected and might have resulted in serological positive animals in the assumed tsetse-free areas. Moreover, it is possible that small tsetse pockets were not detected despite intensive trapping efforts inside the assumed tsetse-free area. From the models available, the most likely scenario in case of tsetse clearing is a disappearance of $T$. congolense (the most pathogen species for cattle) but it is possible that $T$. vivax persist with a different epidemiological pattern, i.e. periodical epidemics instead of an endemic transmission (Desquesnes et al., 2009).

The severity of the symptoms caused by AAT is highly related to the type of cattle breed present in the various regions (Dayo et al., 2009; Toure, 1997). In Basse Casamance in south-eastern Senegal, AAT seem less virulent due to the predominance of the trypanotolerant Ndama cattle. In the areas with zebu cross-breeds, which are mostly located north to the tsetse belt, AAT is considered more virulent as compared to the Niayes (Touré, 1972). The serological and parasitological prevalence measured in this study are similar to the results of previous studies carried out in 1965 and 1969, which also revealed high variations in the prevalence rates between the various localities of the Niayes and La Petite Côte. In places where the forests have been completely replaced with agricultural areas, cattle are kept far from the tsetseinfested habitats and the prevalence remains low. The prevalence was however much higher in those areas where the preferred tsetse habitats have been preserved (e.g. Sangalkam, Noflaye, and Bambilor) and where parasitological prevalences of T. vivax up to $50 \%$ have been observed during the rainy season (Touré, 1972). In southern Senegal, T. congolense predominates (65\% of the infections) (Fall et al., 1993) and even in trypanotolerant breeds such as Ndama, AAT reduces significantly animal draught power and hematocrite (Seck et al., 2002).

The parasitological survey complemented the entomological baseline data collection effort and aimed at the indirect detection of presence of tsetse (Barclay \& Hargrove, 2005; Vreysen, 2005). As a result, in sites with a herd prevalence above $10 \%$ and where the distance to the nearest tsetse fly captured was more than $10 \mathrm{~km}$ (e.g. Mboro, Joal), additional entomological sampling was carried out. Despite these intensified trapping efforts of up to 30 days, no additional tsetse populations were detected. The development of a sound control strategy that aims at eradication of the G.p.gambiensis population and the removal of AAT in the Niayes and La Petite Côte will need to take into account both the data emanating from the entomological and the described parasitological and serological surveys. Even when further trapping failed to detect tsetse, the presence of parasitological and serological positive animals could be an indication of the presence of undetected relic pockets of tsetse flies and these zones should be considered as part of the target area of the area-wide eradication effort. The data of the surveys presented in this paper corroborate the outcome of the entomological data collection (Bouyer et al., 2010) and the population genetics study (Solano et al., 2010) that the G. p. gambiensis populations of the Niayes and La Petite Côte are isolated from the remainder of the tsetse belt in southeastern Senegal.

The entomological, parasitological and serological surveys will be followed by a socio-economic study to evaluate the economical impact of AAT in this area, and to assess potential benefits of its elimination in relation to the total cost of the campaign. These data will not only be crucial to raise the necessary funds to implement the eradication campaign, but it will undoubtedly show 
the great benefits that could emanate from an AW-IPM campaign aimed at the creation of a sustainable free zone of G.p.gambiensis in Western Senegal.

\section{ACKNOWLEDGEMENTS}

W

e are very thankful to the veterinary staff involved in the field studies, particularly Abdou Gaye Mbaye, Babacar Camara, Babel Sow, Aïda Gueye Thiam, Mamadou Demba, Alphonse Manga, Mahanta Ndao, Alioune Ndiaye and Mansour Fall. We are indebted to the Direction des Services Vétérinaires and ISRA-LNERV for providing excellent working conditions.

\section{REFERENCES}

Ba Diao M. Situation et conditions de développement de la production laitière intensive dans la Niayes au Sénégal. Thèse de biologie animale. Université Cheikh Anta Diop, Dakar, 2005, $138 \mathrm{p}$

Barclay H.J. \& Hargrove J.W. Probability models to facilitate a declaration of pest-free status, with special reference to tsetse (Diptera: Glossinidae). Bulletin of Entomological Research, 2005, 95, 1-11.

Bauer B., Amsler-Delafosse S., Clausen P., Kabore I. \& PetrichBAuER J. Successful application of deltamethrin pour on to cattle in a campaign against tsetse flies (Glossina spp.) in the pastoral zone of Samorogouan, Burkina Faso. Tropical Medicine and Parasitology, 1995, 46, 183-189.

Bauer B., Gitau D., Oloo F.P. \& Karanja S.M. Evaluation of a preliminary trial to protect zero-grazed dairy cattle with insecticide-treated mosquito netting in Western Kenya. Tropical Animal Health and Production, 2005, 38, 31-36.

Bouyer J., Guerrini L., Desquesnes M., De la Rocque S. \& Cuisance D. Mapping African Animal Trypanosomosis risk from the sky. Veterinary Research, 2006, 37, 633-645.

Bouyer J., Seck M.T., Sall B., Guerrini L. \& Vreysen M.J.B. Stratified entomological sampling in preparation of an areawide integrated pest management programme: the example of Glossina palpalis gambiensis in the Niayes of Senegal. Journal of Medical Entomology, 2010, in press.

Bouyer J., Stachurski F., Gouro A. \& Lancelot R. Control of bovine trypanosomosis by restricted application of insecticides to cattle using footbaths. Veterinary Parasitology, 2009, 161, 187-193.

Bouyer J., Stachurski F., Kaboré I., Bauer B. \& Lancelot R. Tsetse control in cattle from pyrethroid footbaths. Preventive Veterinary Medicine, 2007, 78, 223-238.

Conover W.J. Practical Nonparametric Statistics. John Wiley \& Sons, New York, 1971, 295-301.

Cuisance D., Politzar H., Merot P. \& Tamboura I. Les lâchers de mâles irradiés dans la campagne de lutte intégrée contre les glossines dans la zone pastorale de Sidéradougou, Burkina Faso. Revue d'Elevage et de Médecine vétérinaire des Pays tropicaux, 1984, 37, 449-468.
Dayo G.K., Thevenon S., Berthier D., Moazami-Goudarzi K., Denis C., Cuny G., Eggen A. \& Gautier M. Detection of selection signatures within candidate regions underlying trypanotolerance in outbred cattle populations. Molecular Ecology, 2009, 18, 1801-1813.

Delafosse A., Bengaly Z. \& Duvallet G. Utilisation du test ELISA de détection des antigènes circulants de trypanosomes dans le cadre d'un suivi épidémiologique dans la zone de Sidéradougou. Revue d'Élevage et de Médecine vétérinaire des Pays tropicaux, 1996, 49, 32-37.

Desquesnes M., Bengaly Z., Millogo L., Meme Y. \& Sakande H. The analysis of the cross- reactions occuring in antibodyELISA for the detection of trypanosomes can improve identification of the parasite species involved. Annals of Tropical Medicine and Parasitology, 2001, 95, 141-155.

Desquesnes M., Biteau-Coroller F., Bouyer J., Dia M.L. \& FoIL L.D. Development of a mathematical model for mechanical transmission of trypanosomes and other pathogens of cattle transmitted by tabanids. International Journal for Parasitology, 2009, 39, 333-346.

Desquesnes M. \& Davila A.M.R. Applications of PCR-based tools for detection and identification of animal trypanosomes: a review and perspectives. Veterinary Parasitology, 2002, 109, 213-231.

Desquesnes M. \& Dia M.L. Mechanical transmission of Trypanosoma congolense in cattle by the African tabanid Atylotus agrestis. Experimental Parasitology, 2003a, 105, 226-231.

Desquesnes M. \& DiA M.L. Trypanosoma vivax: mechanical transmission in cattle by one of the most common African tabanids, Atylotus agrestis. Experimental Parasitology, 2003b, 103, 35-43.

Desquesnes M. \& Dia M.L. Mechanical transmission of Trypanosoma vivax in cattle by the African tabanid Atylotus fuscipes. Veterinary Parasitology, 2004, 119, 9-19.

Dyck V.A., Hendrickx G. \& Robinson A.S. Sterile insect technique. Springer, IAEA, Vienna, Austria, 2005, 787 p.

Fall A. et al. Productivité et pathologie du bétail ndama. Site de Kolda. Entomologie et santé animale (CRZ Kolda, DRPSA-ISRA), 1993, 7 p.

GreEn C.H. Bait methods for tsetse fly control. Advances in Parasitology, 1994, 34, 229-291.

GuerRINI L. \& Bouyer J. Mapping African Animal Trypanosomosis risk: the landscape approach. Veterinaria Italiana, 2007, 43, 643-654.

Itard J., Cuisance D. \& TACher G. Trypanosomoses: Historique - Répartition géographique, in: Principales maladies infectieuses et parasitaires du bétail. Europe et Régions chaudes. Lefèvre P.C., Blancou J., Chermette R. (Eds), Lavoisier, Paris, 2003, 1607-1615.

ITARD J. \& FrézIL J.L. Trypanosomoses: Symptômes et lésions, in: Principales maladies infectieuses et parasitaires du bétail. Europe et Régions chaudes. Lefèvre P.C., Blancou J., Chermette R. (Eds), Lavoisier, Paris, 2003, 1657-1667.

KLASSEN W. Area-wide integrated pest management and the sterile insect technique, in: Sterile insect technique. Principles and practice in area-wide integrated pest management. Dyck V.A., Hendrichs J., Robinson A.S. (Eds), Springer, Dordrecht, The Netherlands, 2005, 39-68. 
Lefrançois T., Solano P., de La Rocque S., Bengaly Z., ReifenBerg J.M., Kabore I. \& Cuisance D. New epidemiological data on Animal Trypanosomosis by molecular analysis in the pastoral zone of Sidéradougou, Burkina Faso. Molecular Ecology, 1998, 7, 897-904.

Morel P.C. \& Touré S. Glossina palpalis gambiensis Vanderplank 1949 (Diptera) dans la région des Niayes et sur la Petite Côte (République du Sénégal). Revue d'Élevage et de Médecine vétérinaire des Pays tropicaux, 1967, 20, 571-578.

Mulligan H.W. The African Trypanosomes. G. Allen \& Unwin LTD, London, 1970, 950 p.

Politzar H. \& Cuisance D. An integrated campaign against riverine tsetse flies Glossina palpalis gambiensis and Glossina tachinoides by trapping and the release of sterile males. Insect Science and its Application, 1984, 5, 439-442.

Reifenberg J.M., Cuisance D., Frezil J.L., Cuny G. \& Duvallet G. Comparison of the susceptibility of different Glossina species to simple and mixed infections with Trypanosoma (Nannomonas) congolense savannah and riverine forest types. Medical and Veterinary Entomology, 2008, 11, 246-252.

SAlEh K.M., Mussa W.A., Juma K.G. \& VReYSEn M.J.B. Eradication of Glossina austeni from the island of Unguja confirmed: results of 2 years of post-eradication monitoring activities, in: $25^{\text {th }}$ meeting of the International Scientific Council for Trypanosomiasis Research and Control, Mombasa, Kenya, 27 September - 1 October, 1999, 231-238.

Seck M.T., Fall A., DiaïTÉ A., Diockou A. \& Dieng M. Effet de l'infection trypanosomienne sur les performances au travail des taurins Ndama trypanotolérants en zone sub humide du Sénégal. Revue d'Élevage et de Médecine vétérinaire des Pays tropicaux, 2002, 55, 109-115.

Solano P., Kaba D., Ravel S., Dyer N., Sall B., Vreysen M.J.B., Seck M.T., Darbyshir H., Gardes L., Donnelly M.J., De Meeûs T. \& BOUYER J. Tsetse population genetics as a tool to choose between suppression and elimination: the case of the Niayes area in Senegal. Plos Tropical Neglected diseases, 2010, e692, doi:10.1371/journal.pntd.000092.

Touré S. Les glossines (Diptera, glossinidae) du Sénégal : Écologie, répartition géographique et incidence sur les trypanosomoses. Revue d'Élevage et de Médecine vétérinaire des Pays tropicaux, 1971, 24, 551-563.

Touré S. Lutte contre Glossina palpalis gambiensis dans la région des niayes du Sénégal. Revue d'Élevage et de Médecine vétérinaire des Pays tropicaux, 1973, 26, 339-347.

Touré S. Note sur quelques particularités dans l'habitat de Glossina palpalis gambiensis Vanderplank, 1949 (Diptera, Glossinidae) observées au Sénégal. Revue d'Élevage et de Médecine vétérinaire des Pays tropicaux, 1974, 27, 81-94.

Touré S.M. Trypanotolerance. Review of knowledge. Revue d'Élevage et de Médecine vétérinaire des Pays tropicaux, 1997, 30, 157-174.

Touré S.M. Rapport sur les campagnes de lutte contre les glossines dans la région des Niayes du Sénégal en vue de l'éradication des trypanosomiases (Dakar, IEMVT, ISRA/ LNERV), 1972, 22 p.

Van den Bossche P., de La Rocque S., Hendrickx G. \& Bouyer $\mathrm{J}$. A changing environment and the epidemiology of tsetse- transmitted livestock trypanosomiasis. Trends in Parasitology, 2010, 26 (5), 236-243.

Vreysen M., Robinson A.S. \& Hendrichs J. Area-Wide Control of Insect Pests, From research to field implementation. Springer, Dordrecht, The Netherlands, 2007, 789 p.

VReysen M.J.B. Monitoring sterile and wild insects in area-wide integrated pest management programmes, in: Sterile insect technique. Principles and practice in area-wide integrated pest management. Dyck V.A., Hendrichs J., Robinson A.S. (Eds), Springer, Dordrecht, The Netherlands, 2005, 325-361.

Reçu le 5 mai 2010 Accepté le 19 mai 2010 